\title{
Peace Agreements through Rituals in Areas of Con- frontation in the Viking Age ${ }^{1}$
}

\author{
STEFAN OLSSON \\ University of Bergen
}

\begin{abstract}
The aim of this paper is to discuss peace agreements and rituals from the perspective of the history of religions. Hostages, fosterages, intermarriages, and other ritual activities were associated with peacemaking during the Viking Age. These ritual activities will be discussed in relation to a proposed conflict and consensus model on the macro and micro levels, with examples from England and Iceland. The examples include the treaties between the Viking ruler Guthrum and Alfred the Great in the 880s as well as conflicts and agreements in the Landnámabók and the Íslendingabók, in addition to iconography (some archaeological objects) and place names. Through these examples I will present an analysis of peace agreements, or peacemakings, as mutual understandings, as well as power relations within a ritual framework. The agreements in the examples are also seen in relation to other societal activities and forces such as economy, politics, and law. The paper brings together a synthesis of previous research and new readings and interpretations of primary sources.
\end{abstract}

Keywords: Peace processes, hostages, fosterages, intermarriages, Viking Age, conflicts, conflict solutions, rituals, Iceland, England

What is a peace process? Peace processes have rarely been examined in Viking Age Studies. Some medieval historians, however, have focused on peace, or the means to stabilise a society. The medieval historian Gerd Althoff has discussed the nature of vertical bonds between German nobles. Others, such as the historians Lars Hermanson and Jón Viðar Sigurðson, have stressed the importance of personal bonds, 'friendship', within Scandinavia and Iceland during the Viking Age and the Middle Ages (Jón Viðar

1 The article is an expansion and translation into English of some sections of Part I of my doctoral dissertation Gísl: givande och tagande av gisslan som rituell handling i fredsprocesser under vikingatid och tidig medeltid ('Gísl: Giving and Taking of Hostages as a Ritual Act in Peace Processes during the Viking Age and Early Middle Ages') (Bergen 2016). A shorter Swedish version has been published in Krig och fred $i$ vendel- och vikingatida traditioner (Stockholm 2016). 
Sigurðsson 1999; Althoff 2004; Hermanson 2009; Kershaw 2011). These studies describe the bonds that maintained a society from within, i.e. vertical bonds of friendship. Through such bonds a ruler could control a territory or subjugate the territory of a rival.

Within the history of religions - in addition to a focus on mythical narratives such as the one about the so-called Fróða friðr (Froði's peace) - analyses have been undertaken to determine the vertical bonds of 'friendship' in relation to the power ideology of rituals, or in relation to the cosmological superstructure of the Viking Age hall (e.g. Sundqvist 2002, 2016; Nordberg 2003). In my investigation I will focus on how counterparts, i.e. rulers and their subordinates, but also on how people at other societal levels communicated across territorial boundaries during peace processes. I will especially emphasise horizontal, rather than vertical, bonds, and suggest how rituals may have functioned as a communicative means to reach consensus between conflicting sides.

\section{Territorial boundaries, consensus, and communicative acts}

A conflict may occur either (a) across borders or (b) within a society. In this paper my concern is with the former, even if the distinction between the two may be difficult to discern. I define these boundaries as areas of confrontation.

If a border, or territorial boundary, was the subject of low-level warfare and temporary peace agreements, it must, contrary to the stable Limes Germanicus in the Roman Age, have been maintained by certain instrumental means. The historian Eva Österberg describes such means in an article about farmers and central powers in border societies (Småland) in early modern Sweden (Österberg 1989, 73ff.). Although Österberg describes conflicts within border societies in the 16th and 17th centuries controlled by a feudal state, she emphasises the mutual agreements in certain communicative spaces. She is influenced by the Marxist consensus concept, but uses it at the microlevel. The concept of consensus is understood as a solution of mutual agreements through a willingness to negotiate and communicate, where the level of interaction is important. Österberg's understanding of conflicts in border societies is crucial for my own understanding of peace processes across areas of conflict. Borders and boundaries are understood as areas which must be upheld communicatively. I define these borders 
and boundaries as areas of confrontation. ${ }^{2}$ These existed both within and outside a society. An example of an area of confrontation is the present-day Southern Göteborg Archipelago, which was the venue for various meetings involving trade, but also peace conferences, during the Viking Age and early Middle Ages. ${ }^{3}$ The ideas of Österberg might therefore be used to analyse the conflict and consensus of border societies during the Viking Age (Österberg $1989,74-6)$. In my opinion her principle of agreements can also be used in analysing Viking Age society. Österberg $(1989,73-6)$ understands consensus as a mutual will to reach an agreement, where the willingness to negotiate is determined by the level of interaction.

Certain communicative spaces existed in the areas of confrontation. Österberg mentions the assembly places in Småland, still referred to in the 16th century as the (Swe) tingsplatser, 'thingsteads', as such communicative spaces. It seems likely that ritual places, thingsteads, and other kinds of gathering place also had this communicative function in the areas of confrontation during the Viking Age. In recent years it has been suggested, for example by the Scandinavist Stefan Brink (1997, 403ff.), that both cult places and thingsteads were multifunctional (see also Sundqvist 2002, 101ff.), but this idea has been disputed. ${ }^{4}$ I will not discuss this here, but would like to add another aspect: the mobile features of both cult places and thingsteads. The mobile cult place might be compared to the traditional practices of nomadic peoples such as the Sami, but also to lifestances and religions such as Islam. ${ }^{5} \mathrm{~A}$ mobile feature of a cult place is mentioned in the Landnámabók, when stocks from high seats or coffins were brought from the homelands and discarded off the Icelandic coast. ${ }^{6}$ This might be compared to Sundqvist, who claims that the cultic object seiðhjallr was used only in times of need and not permanently (Sundqvist 2012). The mobile feature could also be a

2 According to the Oxford English Dictionary (OED) 'conflict' means 'strike together', 'clash', 'contend' (OED 1989, 713). It may further be related to 'collision', 'to clash', 'to be at variance', 'to be incompatible' (OED 1989, 713). I will instead rely on the OED definition of 'confrontation' as 'the bringing of persons face to face; esp. for examination of the truth' (OED 1989, 719). It may also be related to 'the coming of countries, parties, etc., face to face: used to a state of political tension with or without actual conflict' (OED 1989, 719).

3 Several sources describe Brännö (Brenneyja) as an island where kings met every third year for festivities.

4 In a recent article the archaeologists Sarah Semple and Alexandra Sanmark (2008, 245-259) cast some doubt on the multifunctional thingstead. Andreas Nordberg $(2011,21)$ is cautious concerning the division between funeral place and cult place.

5 The goahti of the Sami could be multifunctional even if the construction differed depending on location. In Islam the prayer mat becomes a cultplace.

6 This custom can be intermingled with Christian imaginations, since Christians in the Landámabók practise the same custom. 
characteristic of thingsteads. Torsten Blomkvist touches on the mobile feature of the thingstead in stressing the distinction between gatherings and places which were fixed in the landscape (T. Blomkvist 2002, 104ff.). The Hirdskraa (Hirdloven ca. 1273) describes how the spoils of war were divided: they tied a vébǫnd and shared the spoils within that area. ${ }^{7}$ Saxo Grammaticus (Book 8) also mentions this custom. I will not further outline the mobility theme here. It seems, however, that times of mobility such as war, plague, or drought have had some impact on the nature of ceremonies and rituals, which may also have influenced where people met and how they interacted.

I will describe the functions of those communicative spaces and in areas of confrontation later in this paper. First, it is necessary to describe the society in which the communicative spaces and areas of confrontation occurred.

\section{Development of society, spacial and temporal variation}

Some historians have pointed out the importance of temporal variations and societal changes during the Viking Age and the early Middle Ages. Sverre Bagge (1986, 158ff.) and Nils Blomkvist $(2005,265)$, for example, have described a process of change for early medieval Norway and Gotland, respectively. Bagge portrays the pre-state society as decentralised, dominated by a ruler and competitive 'big men' (Sw stormän; OI mikill maðr), and a societal web which relied upon personal bondage. The state society was dominated by a king with a dependent aristocracy, ground rents, and a fixed societal hierarchy (Bagge 1986, 81ff., 92f., 97f.). The means to achieve this fundamental societal change can be seen in the directed mission in late Iron Age societies such as Saxony (9th century) and Norway (late 10th century). Archaeologists like Alexandra Sanmark (2004, 43-53, 91-106) have also drawn attention to this change.

By 'society' I mean a society in the early stages of state formation. It was characterised by periods of peace and violence. In this period there was also a horizontal division of what Brink (1997, 403f.), in a study of aspects of space and territoriality in Early Scandinavia, calls the administrative divisions of OSw rike, land and hundrade. It is my purpose to distinguish the personal bonds occurring among groups and individuals in and between such administrative divisions.

I will present a model as a tool for understanding the relationships between society, areas of confrontation, and communicative spaces. Its purpose

7 Hirdloven ch. 33: Um Pat skipti et guð getær sigr [oc] hærfong. 
is to describe the dynamic processes before, during, and after a conflict. It is almost a truism among political scientists that a society reshapes after pandemics, war, natural disasters, or other crises. Historians like Thomas Lindqvist (1988, 32f.; cf. Stylegar 1999, 116f., 122ff.) have pointed out that the main reason for war or raids during the Viking Age was plunder. But crises such as drought or plague seem also to have caused migrations and, therefore, engagements (fig.1).

Interest - mutual or unilateral - in creating peace may arise during conflicts. In the Viking Age and early Middle Ages such interest was located in communicative spaces at various levels. There were at least three steps in these peace processes.

The first step was the establishing of social relations through ceremonies involving rituals like oaths, gift-giving, banquets and perhaps a decision to exchange hostages and tributes (ON geld), and to intermarry. These ritual performances often (but not always) occurred in communicative spaces such as things and halls. The symbolic expressions of these ritualistic performances varied and depended on the situation in which they occurred.

The next was the stabilising of economic relations, such as trade or cooperation between crafts, and access to resources. This might mean admission to fertile lands, pastures, woods, and coastal areas with harbours and fishing rights, etc. These trade cooperations or land sharings between opposing sides might be implemented through ritual.

Finally, the peace agreement needed to gain legal force. It might be written, but was in most cases oral. The agreement had then to be accepted by both sides.

These steps were not necessarily communicated at assembly places; they might also be communicated at market or other societal spaces which were sometimes temporary. These spaces were flexible in their function, but existed within the areas of confrontation. An important aspect was the societal consequences of the peace processes. Conflicts may have brought an influx of new ideas which might be seen within the society at the judicial, societal, and economic levels, and these were reflected in the sources that described the events.

The model may help us in our analysis of the opposing sides, their symbolic actions in peace agreements, and their adaption to the society after the conflict. Clearly, as a model it is merely a simplification of reality. It is also important to stress that peace processes during the Viking Age and early Middle Ages were never straightforward. If, for example, one side was stronger, the weaker had to submit. To underline these differing conditions 
and to exemplify how the model can be used, I will briefly present two case studies. The first deals with the peace processes between Alfred the Great (OE Ælfreed) and the Viking ruler Guthrum (OE Guðrum) in late 9th century England. The second addresses the various conflicts and solutions described in the Icelandic Íslendingabók and Landnámabók. These include conflicts at both the macro and micro levels.

\section{The peace processes between Alfred and Guthrum}

In the second half of the 9th century Wessex (OE Westseaxna rīce) and East Anglia (Éast Engla Rìce) were societies in the midst of dynamic changes which were sometimes at war but which also enjoyed periods of peace. After Alfred the Great, the Christian ruler of Wessex, had defeated Guthrum, the heathen ruler of East Anglia, at the Battle of Edington (OE Eðandune) in Wiltshire between 6th and 12th May 878 (The Anglo-Saxon Chronicle MS F, 71 f.). Christianity gradually gained a foothold in the Danelaw. ${ }^{8}$ According to Alfred's biographer, Asser (d. 909), the Danes fled to a fortification after the battle. The Danes were besieged for two weeks, enduring much hardship, until they surrendered to Alfred. The peace treaty was much to Alfred's advantage. The written treaties cannot be trusted as neutral documents because they are written from the Anglo-Saxon perspective. However, from the perspective of power balance it is important to note that Guthrum was not completely defeated: he kept his lands and thus the ability to raise more troops. This process probably culminated with the death of Eric Haraldsson 'Bloodaxe' (OI Eiríkr Haraldsson) at York in 954.

\section{Ritualistic performances}

The rituals performed during the peace conferences between Alfred and Guthrum exemplify the activities in areas of confrontation that can be analysed with the help of the model. When the first peace conference was held after the Battle of Edington, the Danes sent hostages to the Anglo-Saxons to guarantee the peace. This is an example of the establishment of communication, as envoys were probably also sent.

Asser claims that the 'heathen' swore to leave Alfred's realm, which

8 The term 'Danelaw' (OE Dena lagunema) appears for the first time in the Doom Book (Code of Alfred) of 1008. The term was used more frequently in the 11th and 12th centuries, when the term denoted Yorkshire, Derbyshire, Leicstershire, Northamptonshire, and Buckinghamshire (Hadley 2000, 2 ff.). 
implies that oaths were taken within a ritualistic framework (The Medieval Life of King Alfred the Great, 33; The Anglo-Saxon Chronicle MS F, 71 f.). From other Old English sources we know that these could be ring oaths for the heathens, and an example of what I refer to as the mobile feature of the ritual place, i.e. ritual objects were moved to a place in the area of confrontation which became a communicative space where the oaths were sworn (see Olsson 2012, 69). Guthrum, however, vowed to let himself be baptised.

Seven weeks later Guthrum arrived with a retinue of thirty men for a second peace conference at the royal estate of Wedmore. Guthrum was baptised and Alfred became Guthrum's godfather (The Anglo-Saxon Chronicle MS F, 72).

There is only a brief explanation of the rituals performed when Alfred and Guthrum negotiated and agreed on peace terms. These ceremonies and rituals do not seem to differ from those of peace processes among continental Germanic peoples (see Lundgreen 1995, 603-12; see also Olsson 2012). An understanding of something of its contextual character might be obtained from the theoretical perspective of performance suggested by the historian of religions Catherine Bell (1997, 159-62). Performance models suggest active rather than passive roles for ritual participants, who reinterpret symbols as they communicate them. ${ }^{9}$ Cultural life has come to be seen as the dynamic generation and modification of symbolic systems, as something constantly being created by the community. In performances actions are important. Performances like the exchange of hostages were performances in the sense that they aimed to reach something beyond themselves.

As a description the treaty cannot be considered a neutral text recorded by only one side. Furthermore, it was perhaps written some decades after the peace building. The notion of an Alfred who took pity and chose a limited number of hostages may be a Christian interpolation. Despite this the treaty must be considered contemporary in its original setting. While the peace processes were very much on the terms of the Anglo-Saxons, one can assume that the symbolism in the account, as well as in reality, expressed the symbolism of the victor. However, the heathen Danes and the Christian

9 This type of symbolism can be seen in the history of Normandy by Dudo of Saint-Quentin from the late 10th century. The Duke of Normandy, Rollo, identified as Ganger Hrolf by the Icelanders, was required to kiss the foot of King Charles as a condition of the treaty of Saint-Clair-sur-Epte in 911. Rollo refused to perform this act, and ordered one of his warriors to kneel in his place. The warrior took Charles's foot to his mouth and the king fell on his back (Normandiets historie under de første Hertuger, 62ff.). It must be added that Dudo of Saint-Quentin lived several decades after these events, so the story should be taken with a grain of salt. 
Anglo-Saxons seem to have understood the rituals in a similar way, which indicates that the Danes shared similar knowledge of, and presumptions about, peace processes with the Anglo-Saxons. If we accept the accuracy of the gesture of limiting the number of hostages, it may have been a signal of goodwill in an early form of chivalry.

Oathtaking was involved in the peace processes, combined with the exchange of hostages; it constituted the essential element of rituals (see Kershaw 2011, 17). Formally, the oaths taken by both heathens and Christians were considered equal. There is therefore no clear label for the meeting grounds for these oathswearings and exchange of hostages, and this may confirm some of my assumptions of a temporary communicative space, or spaces, if the rituals were performed not only in one location but also on separate occasions. The Danes may have brought sacred objects such as rings and sworn on them.

This ritual probably gave the impression that Guthrum (OE Guðrum) had formally submitted to Alfred, and it might be understood as consonant with the ideology of a Christian ruler who had no rival but relied on his own auctoritas, 'authority'. However, Alfred also had to give up something to secure this agreement. According to Asser Alfred gave 'many fine houses', probably estates, to Guthrum (The Medieval Life of King Alfred the Great, ch. 35; The Anglo-Saxon Chronicle MS F, 72).

Guthrum may have seen Alfred as an ally. East Anglia was hardly a unified realm, but was rather several separate territories under earls and chieftains, and successive wars weakened Guthrum. The history of the Danelaw has neglected the importance of eccelesiastical power, but alongside royal power it might also have proved useful to Guthrum as a source of alignment for the control and defence of his territory (cf. fig.1) against internal enemies. What is important, however, is that these rituals were performed in communicative spaces, even if the Anglo-Saxons and Danes may have differed in their interpretation of the rituals' significance. The rituals' performances illustrate the first part of the model: the establishment of social relations.

\section{Economic and judicial matters}

When Alfred and Guthrum signed a treaty at Wedmore, the border between Wessex and the Danelaw was constituted. Several years later, between 886 and 890, Alfred and Guthrum signed a new treaty, the Treaty of Alfred and Guthrum, which is preserved in two manuscripts in a body of legislation 
from the late 11th century..$^{10}$ This agreement included the division of the Thames but also some judicial matters and trade relations, which were to some extent ritualised (Die Gesetze der Angelsachsen 1, 126f.).

The treaty constituted: (1) the land boundaries asserted through waterflows up the Thames and some tributaries (the Lea, to Bedford, up the Ouse to Watling Street); asserted (2) that if a man were killed, whether English or Danish, there should be a fine of eight half marks; (3) that if one of the king's thanes was accused of murdering, he should take an oath in the presence of twelve of the thanes, and a man of lower degree in the presence of eleven men, but if he refused he should pay threefold (Die Gesetze der Angelsachsen $1,126 \mathrm{f}$.). The swearing of oaths probably occurred in some sort of communicative space, for example, a thingstead.

The treaty covered some trade issues, including also some rituals. According to the treaty: (4) a guarantor well known (to both sides) should guarantee the acquisition of slaves, horses, and oxen; (5) in the oathswearing it was ordained that neither slaves nor freemen should go to the other side for commerce with cattle and goods without hostages given to show goodwill (Die Gesetze der Angelsachsen 1, 126f.). These are examples of how rituals or ritual actions connected with commercial interests functioned as an access to effect or regulate the area of confrontation. Hostages were a vital strategy in this regulation to avoid conflict. And it is important that the hostages could be used as a tool by both sides and were not necessarily themselves subordinated. In my opinion it is also important to note both the degree of subordination in cases like these but also the possibility they afforded to effect peaceful relations.

The Treaty of Wedmore suggests violence occurred in the area of confrontation. If this were not the case, the regulations would have been unnecessary. It therefore exemplifies the third step in the peace process, in which the agreement became lawful and was accepted by both sides. On this occasion it appears to have been the end of a lengthy process. Almost a decade elapsed between The Treaty of Wedmore and The Treaty of Alfred and Guthrum. The latter was probably the result of the experience gained during this interim period.

I have given examples here from larger areas, realms, which might be analysed with the help of this model. I will also give an example of how a narrative might arise because of confrontations and peace processes. Next,

10 The manuscripts (MS 383) are preserved at Corpus Christi College, Cambridge (Kershaw 2000, 44, 48). The treaty should not be confused with the 11th century agreement Laws of Edward and Guthrum, written by Archbishop Wulfstan II. 
I will show how the model can be used as an analytical tool for understanding feuds and personal disagreements, with examples from the Icelandic Íslendingabók and Landnámabók.

\section{Conflicts and conflict solutions in Íslendingabók and Landnámabók}

The Íslendingabók and the Landnámabók are problematic sources, because there is a time discrepancy of between 130 and 300 years between when they were written and the period they describe, the colonisation and Christianisation of Iceland. I will not address here the extensive debate about their source value. It is enough to note that the conflicts probably originated in the struggle for resources during the Landnám era, during which Iceland was settled (Orri Vésteinsson 1998, 8-9; Hayeur Smith 2004, 16-7; Jón Viðar Sigurðsson 2008, 51).

In early Icelandic society conflicts often occurred at the levels of kin-based groupings and individuals. There were no rulers with the rank of the Earls of Lade (ON Hlaðir) in Trøndelag in Norway, for example. The Icelandic goðar had political and judicial as well as religious functions, but their influence was probably limited and their dominance largely depended on their lands in attractive coastal regions with fertile soils, woods, and access to fishing grounds, harbours, and driftwood. Land disputes were the main cause of the 126 conflicts that I have noted in the Íslendingabók and the Landnámabók (table 1). The blood feud was a special mechanism of violence. In table 1 (in appendix) I have noted the blood feuds which immediately escalated into conflicts where revenge was the single motive. An insult beneath the surface may have caused these feuds.

Other causes of conflict were accusations of witchcraft, heritage disputes, theft, molestation, and murder. The periods of agreement between the conflicts, for which there was some kind of consent, are important here. Naturally the reason for the consent varied. But I would like to emphasise this consent as an attempt at consensus. These are examples of conflict and solutions relieving each other within areas of confrontation.

In the longer perspective the main result of the conflicts during the Landnám era was the creation of the Alpingi, the general assembly, in 930 and the later organisation of legislative districts, fiórðungar, which resulted in territorial strengthening. This is not new information; I merely wish to point out that the experiences drawn from the areas of confrontation strengthened the communicative spaces. 


\section{Areas of confrontation and communicative spaces}

A lack of information makes it difficult to define areas of confrontation. Naturally, this is true of the conflicts in the Íslendingabók and the Landnámabók, where descriptions are cryptic. The locations of the disputes limited the significance of the areas of confrontation: the texts describe how clashes took place on high ground, in valleys, or in the backwoods between farmsteads. These became boundaries when periods of collaboration followed conflict.

In these contexts there are examples of how communicative spaces such as thingsteads and farms could be transformed into areas of confrontation. The Íslendingabók (ch. 5) tells of the chieftains Hönsetore (OI Hænsa-Pórir) and Tunge-Odd (OI Tungu-Oddr), who fought the lawman Thord Gellir (OI Pórðr gellir) several times at the Althing (OI Alpingi).

Another narrative in the Landnámabók tells how Erik the Red (OI Eiríkr Dorvaldsson hinn rauði) broke into the house of Thorgest (OI Porgestr) at Breidabolstead (OI Breiðabólstaðr) to retake his high-seat pillars, which he had entrusted to Thorgest. It is not clear if Breidabolstead functioned as a hof, a cultic building, but perhaps there were some ritual restrictions linked to this place. The break-in was a crime in any case, and Erik was summoned to the thing. This escalated into a blood feud between him and Thorgest.

The feud between Erik and Thorgest is an example of cooperation involving trust from its outset, and it can be compared to the examples given concerning the swearing of oaths. In this case, however, each side may have blamed the other and differed about the nature of Erik's offence. This is another example of regulation in areas of confrontation, since they were both able to affect the result of the feud. Erik and Thorgest met several times at the Thorsness Assembly (OI Pórsnespingi), i.e. at a communicative space.

The model makes possible an analysis of the details of narratives such as the one about Erik and Thorgest which assists in understanding the confrontations and communicative spaces, with a focus on various concessions, demands, and compromises. From a broader perspective mediation between different areas such as hostages, intermarriage, and fostering might then be explained in a wider setting. They were tools to regulate borders or boundaries at different levels and in different contexts in different parts of Scandinavia as well as in the Viking diaspora. The actions could also be seen within a framework in which economy, laws, and social issues belong together and depend on one another.

The story of the thingstead at Thorsness illustrates the need for balancing structures like the thingstead and the presence of negotiators. 


\section{The feud at the Thorsness thingstead}

The feud at the Thorsness thingstead is described in both the Landnámabók (125-126, ch. 85) and the Eyrbyggja saga (14-18, ch. 9-10). Here is a summary of the Landnámabók's account: Thorulf Mostur-Beard (OI Porólfr Mostrarskegg) took possession of a headland between the Staf River (OI Stafá) and the Thors River (OI Pórsá) in the Breidafjord (OI Breiðafierðr). Thorulf named the area Thorsness (OI Pórsnes). Near the headland was the holy mountain of Helgafell. Thorolf also established a hof, which he dedicated to Thor (OI Pórr), and a thingstead for the district assembly (OI heraðsping). An agreement was made between Thorolf and the people who visited the assembly that they should not ease themselves and defile the ground at Thorsness, which was believed to be holy. Instead, a special rock, Dirt Skerry (OI Dritsker), was set aside for the people's need. Thorulf was succeeded by his son Thorstein 'Cod-Biter' (OI Porsteinn porskabítr). Then Thorgrim Kjallaksson (OI Porgrímr Kjallaksson) - a chieftain of the Kiallekings grouping - and his brother-in-law Asgeir of Eyr (OI Ásgeirr á Eyri) refused to go to the rock. Thorstein and Thorgeir the Bent (OI Porgeirr kengr) fought Thorgrim and Asgeir at the assembly and many men from the Kiallekings and the Thorsnessings were killed and wounded before they were separated. However, Thord Gellir took responsibility for a reconciliation, and since neither side gave away, the field was considered polluted by the spilling of blood. It was decided that the thingstead should be moved to the eastern part of the headland, which was now also considered holy (126, ch. 85).

In the more extensive 13th-century version of the Eyrbyggja saga (17-18, ch 10) Thord is attributed with having the solutions to the conflict in detail. Thord, the mightiest of the chieftains of Breidafjord, was called to a peace meeting (OI stefnulag) between the parties, the Kiallekings and the Thorsnessings, and obtained a truce (OI gridr). ${ }^{11}$ He called the fight in the thingstead a breach of the peace (OI friðbrot). It was on his advice that the thingstead was considered polluted and was thus moved inland when neither side was prepared to stand down. He decided that Thorgrim should bear half the cost of the hof and in return receive half its debts (OI hoftollr). Half the men of the assembly were to support Thorgrim. Thorgrim was to assist Thorstein in all his law cases and in the foundation of the new thingstead, however holy Thorstein considered it. According to the Eyrbyggja saga Thord also arranged a marriage between his female relative Thorhild

11 For a discussion of the concepts of griðr and friðr, see Olsson 2016, 267-81. 
(OI Pórhildr), the daughter of his neighbour Thorkel Main-acre (OI Porkell meinaker), and Thorgrim. Bestowed with these honours, Thorgrim took the name gođi, a title which included judicial and cultic functions as well as general leadership positions (see Sundqvist 2009, 22-53).

In this story the ritual actions at the Breidafjord were a means of asserting authority for the people involved. Recently, Sundqvist (2016), with the support of both text sources and archaeological material, has shown that attacks against thingsteads may have had a ritual dimension. If someone severed the peace bands (OI vébǫnd) that surrounded a thingstead or burned down a farm belonging to the opposing side, it could serve as a ritual marker against a hostile rival. According to Sundqvist $(2016,169)$ these actions were performative: i.e. ritual actions had the ability to change society as well as individuals. In my opinion similar power demonstrations can be seen in the confrontation between the Kiallekings and the Thorsnessings.

The confrontation mediated at the thingstead may be related to the model I presented at the beginning of this article:

Social relations were established. In this case it included a wedding and the future common rituals associated with the hof and thingstead.

There were economic settlements concerning the expenses for the hof, whereas debts were seen as shared income between Thorgrim and Thorstein.

Both sides accepted the settlement: both had to give something connected with pride to give away (see below). According to the Eyrbyggja saga the agreement stated that neither side should pay fines for manslaughter and woundings. After the thingstead was moved to the ness, Thord made it the Quarter Thing (fjórðungsping) of all the Westfirthers (OI vestfirðingr), which may be seen as an inclusive act within laws and rituals.

The conflict started when Thorulf Mostur-Beard effected the hallowing of the thingstead. The restrictions were too much for the neighbouring Kiallekings. The Eyrbyggja saga mentions that Thorgrim and Asgeir did not care about the pride of the Thorsnessings, and their hostile actions had begun when Thorstein was very young and had recently succeeded his father. Thorgrim and Asgeir may have seen Thorstein as too weak to oppose them. As was the case with the peace processes between Guthrum and Alfred, this conflict had it roots many years earlier than it was solved. (Thorgrim inherited the conflict from his father).

When the solution was accepted by both sides, the actors strengthened their societal positions. The Eyrbyggja saga (18, ch. 11) tells us that Thorstein became a man of great generosity; he had sixty freemen (OI frelsingja) in his household and often went to sea as a fisherman. Thord, as the text describes, 
confirmed - and even strengthened - his position as leader (lawspeaker) with the establishment of the Quarter Thing. Thorgrim's new honours made him - at least in name - an equal of Thorstein and Thord. He was, however, less powerful than Thorstein, whom he had to support in all his affairs.

In this case economic, legal, social, and religious actions and functions were mixed and renegotiated. In accordance with the model this societal restructuring may be due to times of crisis. The thingstead was thus a multifunctional place and the concept of 'holiness' could therefore be questioned.

Some scholars have pointed out that the Eyrbyggja saga could only make dark assumptions of the past, which is bestowed with sorcery, superstitions, and heathen rituals (e.g. Ármann Jakobsson 2007, 44). Both the Landnámabók (126, ch. 85) and the Eyrbyggja saga (18, ch. 11) state that the Westfirthers used to sacrifice humans at the Quarter Thing at Thor's rock (OI Pórssteinn), or Thor's Boulder, a statement which has been regarded as an exaggeration (see Näsström 2002, 44, 57). On the other hand, Theodore M. Andersson $(2006,154)$ points out that there is little exaggeration in the narrative style of the Eyrbyggja saga, which may reflect the author's intention to 'produce something more like history'.

Even if the story of the Thorsness dwellers cannot be trusted - as it is described in the Eyrbyggja saga and in the sense that it depicts an historical event - the main structure of the story is the same as in the Landnámabók version.

\section{Conclusion}

The model I have used is designed as an analytical tool to investigate what I refer to as areas of confrontation during the Viking and early Middle Ages, when peace and war closely followed each other. Rituals were part of the regulations in these areas. I have given examples from the peace processes between rulers of Wessex and the Danelaw, where the swearing of oaths and other rituals was essential to the regulating of areas of confrontation beyond law and economy. The resolution of this conflict exemplifies how previous experiences contributed to the making of consensus through communicative spaces such as thingsteads, market places, and churches.

In the cases from the Íslendingabók and the Landnámabók the sum of the experiences from different conflicts may explain the emergence of regulations between individuals and groupings. This was the case with the feud between the Kiallekings and the Thorsnessings. The conflict began with the actions of Thorulf Mostur-Beard, who hallowed, and thereby protected, his 
headland. This was accepted for a time by the neighbouring communities. However, the initial agreement was not enough to prevent the conflict from emerging after many years, and it was not until the old thingstead was abandoned and moved to a new place that the conflict ceased, whereupon a new society took shape. With the new societal order balancing regulations such as gift-giving, weddings and economic and judicial collaborations were made possible, which were to an extent ritualistic, as in the English case, and a result of the conflict's solution.

By searching for hierarchies and other vertical patterns, the possibilities for both counterparts in a conflict to affect peace processes can be emphasised and discussed. Such an approach identifies both power and anti-power in peace processes which research would otherwise not elucidate.

STEFAN OLSSON, PhD in religious studies, University of Gävle (external).

E-mail: gusolssst@student.gu.se

Abbreviations

$\begin{array}{ll}\text { OE } & \text { Old English } \\ \text { OI } & \text { Old Icelandic } \\ \text { ON } & \text { Old Norse } \\ \text { OSw } & \text { Old Swedish } \\ \text { Swe } & \text { Swedish }\end{array}$

References

Primary sources

The Anglo-Saxon Chronicle

2000 The Anglo-Saxon Chronicle: a collaborative edition : MS F: a semi-diplomatic edition with introduction and indices, vol. 8. Ed. Peter S. Baker. Cambridge: Brewer.

Die Gesetze der Angelsachsen 1

(1903) 1960 Die Gesetze der Angelsachsen. Die beiden Verträgen mit den Dänen in Ostanglien. Ed. and transl. by Felix Liebermann. Aalen: Scientia.

Ari Porgilsson hinn fróði. Íslendingabók

1967 Nordisk filologi. Serie A, Tekster 5. Ed. Anne Holtsmark. Oslo: Dreyer. 
The Medieval Life of King Alfred the Great

2001 The Medieval Life of King Alfred the Great. A Translation and Commentary on the Text Attributed to Asser. Transl. Alfred P. Smyth. Basingstoke: Palgrave.

Normandiets historie under de første Hertuger.

1979 Dudo, Normandiets historie under de første Hertuger. Transl. Erling Albrectsen. Odense: Odense Universitetsforlag.

Hirdloven

2000 Hirdloven til Norges konge og hans håndgangne menn: Etter AM 322 fol. Ed. and transl. by Steinar Imsen. Oslo: Riksarkivet.

Landnámabók

1968 Íslenzk fornrit 2. Ed. Jakob Benediktsson. Reykjavík: Hið íslenzka fornritafélag.

Secondary literature

Althoff, Gerd

2004 Family, Friends and Followers. Political and Social Bonds in Medieval Europe. Transl. Christopher Carroll. New York: Cambridge University Press.

\section{Andersson, Theodore $\mathrm{M}$.}

2006 The Growth of the Medieval Icelandic Sagas. Ithaca, N.Y.: Cornell University Press.

\section{Ármann, Jakobsson}

2007 Two wise women and their young apprentice. A miscarried magic class. - Arkiv för nordisk filologi 122, 41-57.

\section{Bagge, Sverre}

1986 Borgerkrig og statsutvikling i Norge i middelalderen. - Historisk tidsskrift 65, 145-97.

\section{Bell, Catherine}

1997 Ritual. Perspectives and Dimensions. New York: Oxford University Press.

\section{Brink, Stefan}

1997 Political and social structures in early Scandinavia: 2, Aspects of space and territoriality - the settlement district. - Tor. Meddelanden från Uppsala universitets museum för nordiska fornsaker 28, 389-437. 


\section{Blomkvist, Nils}

2005 The Discovery of the Baltic. The Reception of a Catholic World-System in the European North (AD 1075-1225). Leiden: Brill.

\section{Blomkvist, Torsten}

2002 Från ritualiserad tradition till institutionaliserad religion. Strategier för maktlegitimering på Gotland under järnålder och tidig medeltid. Uppsala: Uppsala universitet.

\section{Hadley, Dawn M.}

2000 'Hamlet and the princess of Denmark'. Lordship of the Danelaw, c. 860-954. - Dawn M. Hadley \& Julian D. Richards (eds), Cultures in Contact. Scandinavian Settlement in England in the Ninth and Tenth Centuries, 107-132. Turnhout: Brepols. (Studies in the Early Middle Ages 2.)

\section{Hayeur Smith, Michèle}

2004 Draupnir's Sweat and Mardöll's Tears. An Archaeology of Jewellery, Gender and Identity in Viking Age Iceland. Oxford: Hedges. (British Archaeological Reports. International Series 1276.)

\section{Hermanson, Lars}

2009 Bärande band. Vänskap, kärlek och brödraskap i det medeltida Nordeuropa, ca 1000-1200. Lund: Nordic Academic Press.

\section{Innes, Matthew.}

2000 Danelaw Identities: Ethnicity, Regionalism, and Political Allegiance. - Dawn M. Hadley \& Julian D. Richards (eds), Cultures in Contact: Scandinavian Settlement in England in the Ninth and Tenth Centuries, 65-88. Turnhout: Brepols.

\section{Jón Viðar Sigurðsson}

1999 Chieftains and Power in the Icelandic Commonwealth. [Transl.] Jean Lundskær-Nielsen. Odense: Odense University Press. (The Viking Collection 12.)

2008 Det norrøne samfunnet. Vikingen, kongen, erkebiskopen og bonden. Oslo: Pax.

\section{Kershaw, Paul}

2000 The Alfred-Guthrum Treaty. Scripting Accommodation and Interaction in Viking-Age England. - Dawn M. Hadley \& Julian D. Richards (eds), Cultures in Contact: Scandinavian Settlement in England in the Ninth and Tenth Centuries, 43-64. Turnhout: Brepols. (Studies in the Early Middle Ages 2.)

2011 Peaceful Kings. Peace, Power and the Early Medieval Political Imagination. New York: Oxford University Press.

\section{Lindkvist, Thomas}


1988 Plundring, skatter och den feodala statens framväxt. Organisatoriska tendenser $i$ Sverige under övergången från vikingatid till tidig medeltid. Uppsala: Uppsala universitet. (Opuscula historica Upsaliensia 1.)

\section{Lundgreen, Michael}

1999 Friedensschluss. - Heinrich Beck et al. (eds), - Reallexikon der germanischen Altertumskunde 9, 606-612. Berlin: de Gruyter.

Nordberg, Andreas.

2003 Krigarna i Odins sal. Dödsföreställningar och krigarkult i fornnordisk religion. Stockholm: Stockholms universitet.

2011 Vad är en kultplats? - Fornvännen 106, 215-231.

Näsström, Britt-Mari.

2002 Blot. Tro och offer i det förkristna Norden. Stockholm: Norstedt.

OED = The Oxford English Dictionary

John Andrew Simpson \& Eva S. Weiner (eds). Oxford: Clarendon Press. (2nd ed.)

\section{Olsson, Stefan}

2012 Gisslan i vikingtida och tidigmedeltida traditioner. - Chaos: skandinavisk tidsskrift for religionshistoriske studier 58, 59-82.

2016 Gísl. Givande och tagande av gisslan som rituell handling i fredsprocesser under vikingatid och tidig medeltid. Unpublished doctorat dissertation. Bergen: Universitetet i Bergen.

\section{Orri Vésteinsson}

1998-2001 Patterns of settlement in Iceland: a study in prehistory. Saga-Book 25, 1-29.

Österberg, Eva

1989 Bönder och centralmakt i det tidigmoderna Sverige. Konflikt - kompromiss - politisk kultur. - Scandia 55, 73-95.

\section{Sanmark, Alexandra}

2004 Power and Conversion: A Comparative Study of Christianization in Scandinavia. Uppsala: Dept. of Archaeology and Ancient History. (Occasional Papers in Archaeology 34.).

\section{Sanmark, Alexandra \& Sarah Semple}

2008 Places of assembly: new discoveries in Sweden and England. - Fornvännen 103, 245-259.

\section{Stylegar, Frans-Arne}

1999 Rikssamling, statsoppkomst og ujevn utvikling: regional variasjon i tidlig middelalder. - Joakim Goldhahn \& Pär Nordqvist (eds), Marxistiska perspektiv inom skandinavisk arkeologi, 111-134. Umeå: 
Institutionen för arkeologi och samiska studier.

\section{Sundqvist, Olof}

2002 Freyr's Offspring: Rulers and Religion in Ancient Svea Society. Uppsala: Uppsala University Library. (Acta Universitatis Upsaliensis. Historia Religionum 21.)

2009 Kultledare i fornskandinavisk religion. Uppsala: Department of Archaeology and Ancient History. (Occasional papers in archaeology 41.).

2011 Var sejdhjällen (fvn. seidhjallr, hjallr) en permanent konstruktion vid kultplatser och i kultbyggnader? - Fornvännen 107, 280-285.

2016 Vapen, våld och vi-platser. Skändande av helgedomar som maktstrategi i det vikingatida Skandinavien. - Håkan Rydving and Stefan Olsson (eds), Krig och fred i vendel-och vikingatida traditioner, 167-198. Stockholm: Stockholm University Press.

\section{Appendix:}

Table 1. Causes of conflict reported in the Íslendingabók and the Landnámabók.

\begin{tabular}{|c|c|}
\hline Land disputes & 35 \\
\hline Blood feud & 18 \\
\hline Murder & 17 \\
\hline Insult & 11 \\
\hline Witchcraft & 9 \\
\hline Duel & 5 \\
\hline Lawsuit & 5 \\
\hline Heritage disputes & 5 \\
\hline Theft & 4 \\
\hline Molestation & 4 \\
\hline Riot of thralls & 2 \\
\hline Suicide & 1 \\
\hline
\end{tabular}


Figure 1. A schematic description of conflicts and conflict solutions in the Viking Age and the early Middle Ages.

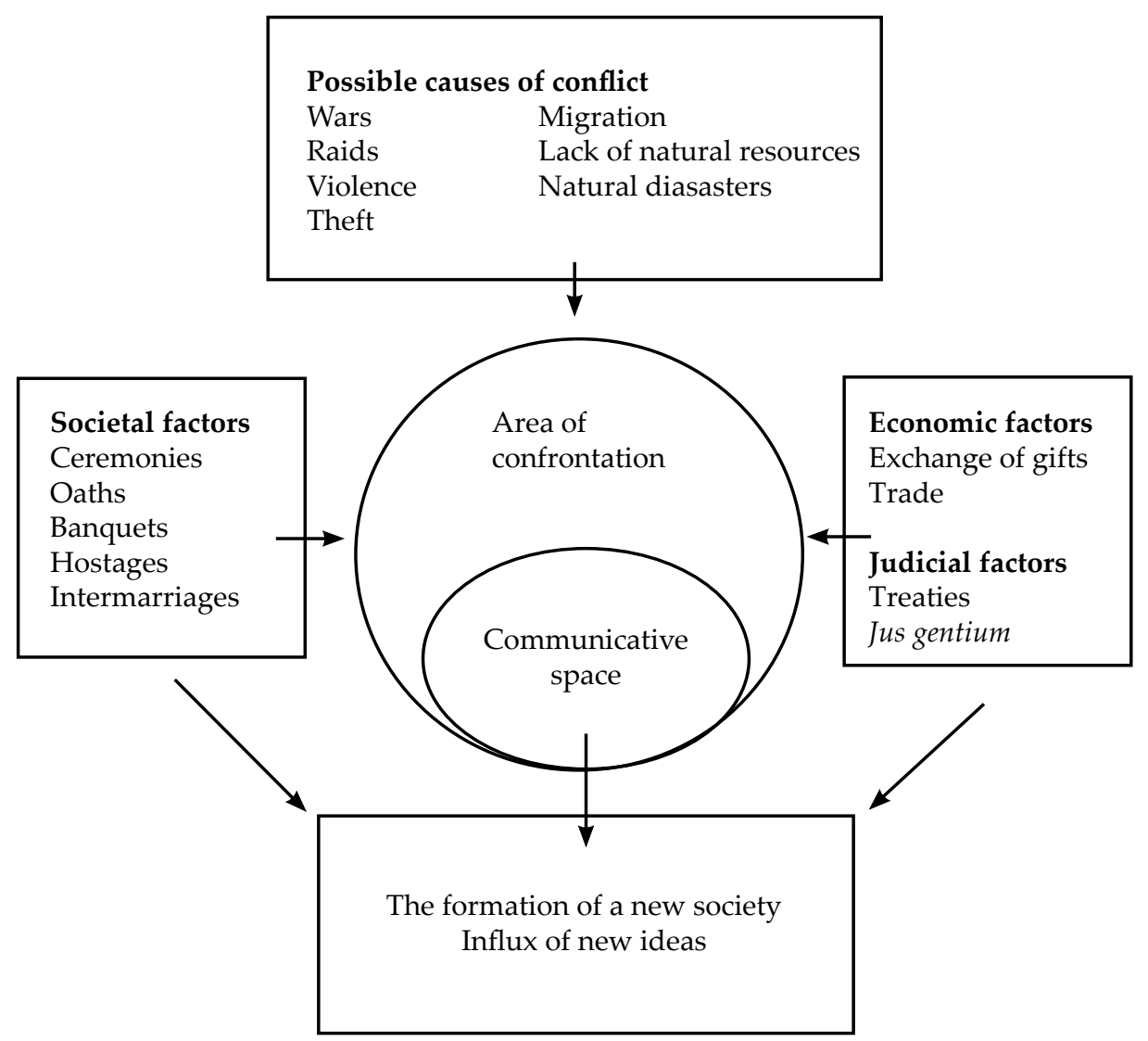

